\title{
Local Politics's Effect on Local E_Procurement: A Study in Three Indonesian Local Governments
}

\author{
Achmad Nurmandi \\ Department of Government Affairs and Administration \\ Jusuf Kalla School of Government \\ Universitas Muhammadiyah Yogyakarta
}

\begin{abstract}
In some local governments of Indonesia, a bigger representation in local parliament means more political power in controlling their local budget. As a result, local procurement process is mostly affected by local politicians although procurement process is applied electronic procurement. In this study we compare three local governments in Indonesia by using meta analysis of previous study on electronic procurement. Quantitative and qualitative research method is used to investigate relationship between private sectors, politicians, and government officers. We found that e-procurement system applications in private/government firms has a positive effect on time efficiency. However, in three local government confirm that There is relationship between procurement information, completeness of information, information on evaluation, contract mechanism, and opportunistic behavior on eprocurement implementation. The local politicians, bureaucrats, and private companies have organized and governed themselves to obtain benefit from "eprocurement" regulation. They did preparation from the budget planning until project procurement announcement in site.
\end{abstract}

Keywords: procurement, e-procurement, corruption, local politics, efficiency, principal agency theory, capture theory, collective action theory.

\section{INTRODUCTION}

Public procurement is the process by which large amounts of public funds are utilized by public entities to purchase goods and services from the private sector. Vast amounts of money are therefore expended through the public procurement system (Nurmandi and Kim, 2015). A procurement system that has loose or opaque rules or rules which are poorly enforced provides opportunities for misuse of the contract award process through corruption or other patronage arrangements. Those in the private sector and their collaborators in the public institutions who benefit from such flawed systems have a very deep vested interest in the maintenance of the status quo.

The interesting question is this part how does the procurement process function in the Indonesian political system? The crucial implication of this low implementation of eprocurement is that the procurement process is designed by predatory politicians, state/private companies, and some bureaucrats. The analysis could be based on the big corruption case investigated by the Anti-corruption Agency (KPK). Based on the KPK report 2012 revealed that from 2004 to 2012, there were 64 members of local councils and national parliament alleged corruption case and 33 mayors and regents were suspected in corruption cases. KPK estimated finances lost due to corruption to be around Rp. 152 trillion. Based on data above, we can conclude corruption in procurement involved high rank government officials and politicians. Thus, in 2012, for the first time Anti-Monopoly Commission (KPPU) handled merger cases due to negligence, giving merger notification by business actors as 
regulated in Government Regulation Number 57 Year 2010 concerning the implementation of Articles 28 and 29 of Law Number 5 Year 1999. To put the number of cases in percentages, these 2 (two) merger cases constitute $1 \%$ of all the 216 cases handled by the Commission. The data indicates that if we look at the aspect of the substance of violated articles, 157 or $73 \%$ of 216 cases or KPPU Decision are related to bid rigging in the procurement of goods and services. In relation to these KPPU decisions, pursuant to the provisions of Article 44 and Article 45 of Law Number 5 Year 1999, a number of business actors filed Objections to the District Court and in fact, due to dissatisfaction about the District Court decisions, the reported business actors also filed appeals to the Supreme Court (MA).

Therefore, it is interesting to see the dynamics of the procurement process e-procurement is implemented. What is the change in procurement decision patterns in bidding selection? What is the extent to which the influence of executive institution and local politicians or interest groups on the decision making process? The discussion is based on interviews with key procurement officials. Getting deeper into the analysis, some procurement cases will be explored in line with addressed issues. The relationship pattern among sub-unit procurement unit can be illustrated.

\section{THEORETICAL FRAMEWORK}

We use literature survey as "the documentation of a comprehensive review of the published and un published work from secondary sources data in the area of specific interest to the researcher" (Sekharan, 1992, p. 37 in Neupane, at al., 2012). This section used a literature survey of public e-procurement anti-corruption factors based on books, academic publications, and government procurement report published by either the foreign institution or the Indonesian institution.

\section{Principal Agency Theory on Procurement}

Given the above, research involving the principal-agency theory would be beneficial. Procurement is a process and a relationship between principal and agency. Government, bureaucrat, or political parties in legislative bodies are the principal and supplier of good or service is the agent. The principal has the formal authority, but in PAT, the attention is on a particular form of formal authority: the authority to impose incentives on the agent (Miller, 2005). However, the relationship between principal and agent has several possible patterns (Miller, 2005 and Zeng, 2008) namely:

1. Asymmetric information. In principal-agent operations of public right, who owns the most information is who has the latent advantage (Soudry, 2007). Besides, it is difficult to check the conspiracy between the agents, even if the consignor is not very difficult to observe, the cost is much more. Therefore, decision-making of the consignor in the government procurement is under the control of the agent who provides information. In fact, the range of government procurement, the way of government procurement, and the quota standard of government procurement are all decided by the agent ultimately. The asymmetric information has provided the possibility that the agent deflects the consignor's target.

2. Incomplete contracts. The principal-agency relation is a kind of contract relation essentially; consignor and agent can standardize both sides' behavior by the way of signing a contract when they are practicing government procurement (Barber, 2007).

3. Opportunism in the supervision of consignors. The consignor must operate the supervision to ensure that the procurement officials carry out the purchasing according to the wishes of the consignor. Le Grand (2003) revealed that roles of "knaves, knights, pawns and queens. Knaves peruse their interests, knights have no-interest and are 
motivated to help other, pawns are moved or controlled by others and queens are those with the most power."

This proposition set the stage for an entire generation of scholars (Goodnow, 1990; Mosher, 1982; Waldo, 1980) and provided the theoretical reasoning behind the "neutral competence" ideal for bureaucrats (Catron, 1989; Kaufman, 1956; Klay, 1983; McSwite, 1997). Yet, a varied and equally vast body of work challenges this dichotomy (Cook, 1998; Demir \& Nyhan, 2008; Denhardt, 1989; Fredrickson, 1997; Heyman, 1987). As Goodsell (2006) writes, "politicians obviously are more policy makers and principals than bureaucrats, but to conclude that the latter never engage in formative or constitutive political activity is shortsighted to the extreme".

Procurement in public organizations has internal demands. Telgen, et al (2007) said that public organizations have to serve many goals at the same time (Murray, 1999). Public organization has very broad and not well defined political goals that have to be taken into account (Premchand,1993). Telgen also mentioned in public procurement there are many stakeholders: obviously these many stakeholders (e.g. citizens, taxpayers, electorate, elected officials, management, and procurement officers) may have different objectives (Murray, 1999). In developing countries a lot of inhibitors exist. It is difficult to tell what is the main bottleneck because a lot of basic aspects of good governance are not in place yet (Backus, 2001), with the following aspects have to be taken into account when examining the risk of implementing egovernance solutions.

- Political stability (elections, democracy or dictatorial regime)

- Level of trust in Government (perception of service levels)

- The importance of Government identity (fragmentation or integration)

- Economic structure (education, agriculture, industry or service)

- Government structure (centralised or decentralised)

- Different levels of maturity (weakest part of the chain determines speed)

- Constituent demand (push or pull)

\section{The capture theory on Procurement}

Looking at the political environment is very important to explain the circumstance. We may assume that the more democratic political configuration is related to more procurement transparency. However, many scholars have tried to investigate the beyond of principal agent theory (Persson, et al, 2010). The predominant theory of corruption within both political science and economics today is the principal-agent model, popularized especially by the work of Susan Rose-Ackerman (1978) and Robert Klitgaard (1988). The principal-agent theory situates the analysis of corruption in the interaction and interrelations that exist within and without public bodies and is based on two key assumptions:1) that a conflict exists between the goals of the so-called principals (who are typically assumed to embody the public interest) and agents (who are assumed to have a preference in favor of corrupt transactions insofar the benefits of such transactions outweigh the costs), and; 2) that agents have more information than the principals, which results in an information asymmetry between the two groups ofactors (Klitgaard 1988; Williams 1999). In fact, the high-level government officials represented by legislators or elected public officials - may institute or manipulate procurement (from writer) policy and legislation in favor of particular interest groups (representing private sector interests and entities or individual units of public bureaucracy competing for higher budgets) in exchange for rents or side payments (Persson, et. al., 2010).

In some local governments of Indonesia, a bigger representation in local parliament means more political power in controlling their local budget. Thus, the point to be emphasized is that 
the decentralization process in Indonesia has largely been hijacked by special interests that have little to gain from local a governance characterized by greater accountability to local communities, transparency, and the like (Hadiz, 2011). Therefore if we analyze e-procurement implementation as a policy execution, it is better to explore theoretical frameworks rather than technical ones (technocratic one) in terms of information technology as such. Hadiz (2011) tried to look at the weaknesses of neo-liberal approach in decentralization policy. Hadiz (2011) moreover said that decentralization is unlikely to produce the kind of technocratic 'good' governance idealized in the neo-institutionalist scheme. This is most vividly illustrated by the rise of political gangsters and thugs - perhaps the ultimate in predators - in the leadership of parties, parliaments and executive bodies at the local level (Hadiz, 2011).

The capture theory of corruption tries to look at elite behavior regarding scarce economic resources. Pearsson (2010) mentioned that researchers and policy makers now seem to agree that the failure of contemporary anti-corruption reforms are not so much the result of a lack of resources as of the absence of stakeholders -including government, civil society, nongovernmental organizations, and ordinary citizens - willing to act as "principals" and, as such, to enforce existing laws and policies (Riley 1998; Robinson 1998;Kpundeh 1998, 2004; Johnston 2005; Amundsen 2006; World Bank 1994).Early studies took a pessimistic view of the potential of collective action to overcome problems, such as elite capture. As a prevention policy to curb corruption, in e-procurement implementation, all actors could have roles as a principals. The public, for example, play both an agents and the principals in term of oversight control.

\section{The collective action theory on Procurement}

Referring to collective action theory done by Mansur Olson, the analysis on the dynamic relations amongst actors is very interesting to address. Mancur Olson (1965) theorized that groups of individuals with a shared interest will not act on behalf of that interest. Rather, he posits that since 'members of a large group rationally seek to maximize their personal welfare, they will not act to advance their common group objectives unless there is coercion to force them to do so' (Olson, 1965: 2). According to Olson, the problem is that there is no incentive for all to share the cost of collective action. Instead, he argues, each member of the group prefers that another member pay the entire cost - hence the 'free rider' problem. Olson does concede, however, that small groups are not only quantitatively, but qualitatively different from large groups, and that with smaller groups the free rider problem is reduced. Moreover, Ostrom's(1990) work takes issue with the conceptualization of the free rider problem and other difficulties associated with collective action. Where previous analysts had limited the possible responses to the collective action quandary to either control by a strong central government or regulation through a system of private property rights, Ostrom presents a third option: individuals can have agency to create their own agreements, institutions and systems of management, which have the capacity to change over time and prevent tragic outcomes. Through a series of case studies of small-scale common pool resources (CPRs), Ostrom examines how in various contexts a 'group of principals who are in an interdependent situation can organize and govern themselves to obtain continuing joint benefits when all face temptations to free-ride, shirk, or otherwise act opportunistically' (Ostrom, 1990).

\section{RESEARCH METHOD}

Research method was employed in this study combining meta analysis, quantitative and qualitative research. Meta analysis research analyzed the current forty reports (40) on eprocurement research. This number is certainly not able to represent a large population. By taking into account that the early implementation of e-procurement in Indonesia most recently started in 2012 so we can realize that the number of e-procurement research is still limited. 
Quantitative research was applied principal agency theory relationship between principal and agents in local procurement. There were 150 respondents from three local government namely Yogyakarta City, Tangerang City and Riau Province. We tested perception of local procurement officers on local procurement process. Qualitative one is applied in order to get more undertanding on local politics influence on procurement process in term of collective action theory.

\section{FINDINGS}

However, at least we can get an overview of the extent to which e-procurement which had been implemented in diverse of time and the model in various agencies of the central government and the local government that might encourage a decrease of corruption of goods and services procurement.

\section{META ANALYSIS ON E-PROCUREMENT RESEARCH}

By reviewing the trend of increasing number of e-procurement units, only 11 units established in 2008, 63 units in 2009, 274 units in 2010, followed by an increase of approximately 300\% in 2001 when the total number of units was 630, and then doubling in 2015.

Table 1.Forty's Institution Public E-Procurement Performance or Expected Outcome Matrix

\begin{tabular}{|c|c|c|c|c|c|c|c|c|c|c|c|c|c|}
\hline & & $\begin{array}{l}\text { Auto } \\
\text { mation }\end{array}$ & $\begin{array}{l}\text { Avoid } \\
\text { unne } \\
\text { cessary } \\
\text { cost }\end{array}$ & $\begin{array}{l}\text { Effici } \\
\text { ent } \\
\text { and } \\
\text { secure }\end{array}$ & $\begin{array}{l}\text { Incre } \\
\text { ase } \\
\text { com } \\
\text { petition }\end{array}$ & $\begin{array}{l}\text { Proces } \\
\text { s } \\
\text { faster } \\
\text { and } \\
\text { easier }\end{array}$ & $\begin{array}{l}\text { Con } \\
\text { trol } \\
\text { and } \\
\text { colla } \\
\text { bora } \\
\text { tion }\end{array}$ & $\begin{array}{l}\text { Moni } \\
\text { toring } \\
\text { and } \\
\text { trac } \\
\text { king }\end{array}$ & $\begin{array}{l}\text { Best } \\
\text { qua } \\
\text { lity }\end{array}$ & $\begin{array}{l}\text { Real } \\
\text { time }\end{array}$ & $\begin{array}{l}\mathrm{Hu} \\
\text { man } \\
\text { inter } \\
\text { face }\end{array}$ & $\begin{array}{l}\text { Con } \\
\text { Sisten } \\
\text { Cy }\end{array}$ & $\begin{array}{l}\text { Trans } \\
\text { Paren } \\
\text { cy and } \\
\text { account } \\
\text { tability }\end{array}$ \\
\hline 1 & $\begin{array}{l}\text { North Sumatera } \\
\text { Province }\end{array}$ & & $\mathrm{X}$ & & & & & & & & & & \\
\hline 2 & Bali Province & $\mathrm{X}$ & $\mathrm{X}$ & $\mathrm{X}$ & $\mathrm{X}$ & $\mathrm{X}$ & & $\mathrm{X}$ & & & & $\mathrm{X}$ & $\mathrm{X}$ \\
\hline 3 & $\begin{array}{l}\text { Central Java } \\
\text { Province }\end{array}$ & $\mathrm{X}$ & $\mathrm{X}$ & & $\mathrm{X}$ & $\mathrm{X}$ & & $\mathrm{X}$ & $\mathrm{X}$ & & & & $\mathrm{X}$ \\
\hline 4 & $\begin{array}{l}\text { Gorontalo } \\
\text { Province }\end{array}$ & $\mathrm{X}$ & $\mathrm{X}$ & & $\mathrm{X}$ & $\mathrm{X}$ & & & & $\mathrm{X}$ & $\mathrm{X}$ & & \\
\hline 5 & Jakarta Province & $\mathrm{x}$ & $\mathrm{X}$ & $\mathrm{X}$ & $\mathrm{X}$ & & & & & & $\mathrm{X}$ & & $\mathrm{X}$ \\
\hline 6 & $\begin{array}{l}\text { Jogjakarta } \\
\text { Special Province }\end{array}$ & $\mathrm{X}$ & $\mathrm{X}$ & & $\mathrm{X}$ & $\mathrm{X}$ & $\mathrm{X}$ & & $\mathrm{X}$ & $\mathrm{X}$ & & & $\mathrm{X}$ \\
\hline 7 & $\begin{array}{l}\text { Riau Island } \\
\text { Province }\end{array}$ & $\mathrm{X}$ & $\mathrm{X}$ & & $\mathrm{X}$ & & & & & & & $\mathrm{X}$ & $\mathrm{X}$ \\
\hline 8 & $\begin{array}{l}\text { West Java } \\
\text { Province }\end{array}$ & $\mathrm{X}$ & $\mathrm{X}$ & & & $\mathrm{X}$ & & & & $\mathrm{X}$ & & $\mathrm{X}$ & $\mathrm{X}$ \\
\hline 9 & Jogyakarta City & $\mathrm{X}$ & $\mathrm{X}$ & $\mathrm{X}$ & $\mathrm{X}$ & $\mathrm{X}$ & & $\mathrm{X}$ & $\mathrm{X}$ & $\mathrm{X}$ & & $\mathrm{X}$ & $\mathrm{X}$ \\
\hline 10 & Tangerang City & $\mathrm{X}$ & $\mathrm{X}$ & $\mathrm{X}$ & & $\mathrm{X}$ & $\mathrm{X}$ & & $\mathrm{X}$ & & $\mathrm{X}$ & $\mathrm{X}$ & $\mathrm{X}$ \\
\hline 11 & $\begin{array}{l}\text { Kutaikartanegara } \\
\text { Regency }\end{array}$ & $\mathrm{X}$ & $\mathrm{X}$ & $\mathrm{X}$ & $\mathrm{X}$ & & $\mathrm{X}$ & $\mathrm{X}$ & $\mathrm{X}$ & & $\mathrm{X}$ & $\mathrm{X}$ & \\
\hline 12 & Banjarmasin City & $\mathrm{X}$ & $\mathrm{X}$ & $\mathrm{X}$ & $\mathrm{X}$ & $\mathrm{X}$ & & & & & & $\mathrm{X}$ & \\
\hline 13 & Bandung City & $\mathrm{X}$ & $\mathrm{X}$ & $\mathrm{X}$ & & & $\mathrm{X}$ & & & & $\mathrm{X}$ & $\mathrm{X}$ & \\
\hline 14 & Kota Banjarbaru & $\mathrm{X}$ & $\mathrm{X}$ & $\mathrm{X}$ & $\mathrm{X}$ & $\mathrm{X}$ & & & & & & & \\
\hline 15 & Jambi City & $\mathrm{X}$ & & $\mathrm{X}$ & $\mathrm{X}$ & & & & & & & $\mathrm{X}$ & \\
\hline 16 & Cirebon City & $\mathrm{X}$ & & & & & & & & & & & \\
\hline 17 & Denpasar City & $\mathrm{X}$ & $\mathrm{X}$ & $\mathrm{X}$ & $\mathrm{X}$ & & & & & & & & $\mathrm{X}$ \\
\hline 19 & Pontianak City & $\mathrm{X}$ & $\mathrm{X}$ & $\mathrm{X}$ & $\mathrm{X}$ & & & & & & $\mathrm{X}$ & & $\mathrm{X}$ \\
\hline 20 & Metro City & $\mathrm{X}$ & & & $\mathrm{X}$ & & & & & & & & \\
\hline
\end{tabular}


Nurmandi, A. (2017). Local Politics's Effect on Local E_Procurement: A Study in Three Indonesian Local Governments. Advances in Social Sciences Research Journal, 4(16) 271-286.

\begin{tabular}{|c|c|c|c|c|c|c|c|c|c|c|c|c|c|}
\hline & & $\begin{array}{l}\text { Auto } \\
\text { mation }\end{array}$ & $\begin{array}{l}\text { Avoid } \\
\text { unne } \\
\text { cessary } \\
\text { cost }\end{array}$ & $\begin{array}{l}\text { Effici } \\
\text { ent } \\
\text { and } \\
\text { secure }\end{array}$ & $\begin{array}{l}\text { Incre } \\
\text { ase } \\
\text { com } \\
\text { petition }\end{array}$ & $\begin{array}{l}\text { Proces } \\
\text { s } \\
\text { faster } \\
\text { and } \\
\text { easier }\end{array}$ & $\begin{array}{l}\text { Con } \\
\text { trol } \\
\text { and } \\
\text { colla } \\
\text { bora } \\
\text { tion }\end{array}$ & $\begin{array}{l}\text { Moni } \\
\text { toring } \\
\text { and } \\
\text { trac } \\
\text { king }\end{array}$ & $\begin{array}{l}\text { Best } \\
\text { qua } \\
\text { lity }\end{array}$ & $\begin{array}{l}\text { Real } \\
\text { time }\end{array}$ & $\begin{array}{l}\mathrm{Hu} \\
\text { man } \\
\text { inter } \\
\text { face }\end{array}$ & $\begin{array}{l}\text { Con } \\
\text { Sisten } \\
\text { Cy }\end{array}$ & $\begin{array}{l}\text { Trans } \\
\text { Paren } \\
\text { cy and } \\
\text { account } \\
\text { tability }\end{array}$ \\
\hline 21 & Kebumen City & $\mathrm{X}$ & $\mathrm{X}$ & $\mathrm{X}$ & $\mathrm{X}$ & & & & & & $\mathrm{X}$ & & $\mathrm{X}$ \\
\hline 22 & Palu City & $\mathrm{X}$ & & & $\mathrm{X}$ & & & & & & & & $\mathrm{X}$ \\
\hline 23 & Bogor City & $\mathrm{X}$ & $\mathrm{X}$ & $\mathrm{X}$ & $\mathrm{X}$ & & $\mathrm{X}$ & & $\mathrm{X}$ & & $\mathrm{X}$ & $\mathrm{X}$ & $\mathrm{X}$ \\
\hline 24 & Surabaya City & $\mathrm{X}$ & $\mathrm{X}$ & $\mathrm{X}$ & $\mathrm{X}$ & & & & $\mathrm{X}$ & $\mathrm{X}$ & & $\mathrm{X}$ & $\mathrm{X}$ \\
\hline 25 & Makassar City & $\mathrm{X}$ & & $\mathrm{X}$ & & & & & & & & & \\
\hline 26 & Malang Regency & $\mathrm{X}$ & $\mathrm{X}$ & $\mathrm{X}$ & & $\mathrm{X}$ & & & & & & & $\mathrm{X}$ \\
\hline 27 & Seragen Regency & $\mathrm{X}$ & $\mathrm{X}$ & & & $\mathrm{X}$ & & & & $\mathrm{X}$ & & $\mathrm{X}$ & $\mathrm{X}$ \\
\hline 28 & PLN Malang & $\mathrm{X}$ & & $\mathrm{X}$ & & $\mathrm{X}$ & & & & & & & \\
\hline 29 & Finane Ministry & $\mathrm{X}$ & $\mathrm{X}$ & $\mathrm{X}$ & & & & & & & $\mathrm{X}$ & $\mathrm{X}$ & $\mathrm{X}$ \\
\hline 30 & $\begin{array}{l}\text { Public Work } \\
\text { Ministry }\end{array}$ & $\mathrm{X}$ & $\mathrm{X}$ & $\mathrm{X}$ & $\mathrm{X}$ & & $\mathrm{X}$ & & & & & $\mathrm{X}$ & $\mathrm{X}$ \\
\hline 32 & Dongala Regency & $\mathrm{X}$ & $\mathrm{X}$ & $\mathrm{X}$ & $\mathrm{X}$ & $\mathrm{X}$ & & & & & & & \\
\hline 33 & Toli-toli Regency & $\mathrm{X}$ & $\mathrm{X}$ & & $\mathrm{X}$ & $\mathrm{X}$ & & & & & & & \\
\hline 34 & Buol Regency & $\mathrm{X}$ & $\mathrm{X}$ & & $\mathrm{X}$ & $\mathrm{X}$ & & & & & & & \\
\hline 35 & ArigiMuontong & $\mathrm{X}$ & $\mathrm{X}$ & & $\mathrm{X}$ & $\mathrm{X}$ & & & & & & & \\
\hline 36 & Poso Regency & $\mathrm{X}$ & $\mathrm{X}$ & & $\mathrm{X}$ & $\mathrm{X}$ & & & & & & & \\
\hline 37 & Banggai Regency & $\mathrm{X}$ & $\mathrm{X}$ & & $\mathrm{X}$ & $\mathrm{X}$ & & & & & & & \\
\hline 38 & $\begin{array}{l}\text { Morowali } \\
\text { Regency }\end{array}$ & $\mathrm{X}$ & $\mathrm{X}$ & & $\mathrm{X}$ & $\mathrm{X}$ & & & & & & & \\
\hline 39 & $\begin{array}{l}\text { TojoUna-una } \\
\text { Regency }\end{array}$ & $\mathrm{X}$ & $\mathrm{X}$ & & $\mathrm{X}$ & $\mathrm{X}$ & & & & & & & \\
\hline 40 & Sigi Regency & $\mathrm{X}$ & $\mathrm{X}$ & & $\mathrm{X}$ & $\mathrm{X}$ & & & & & & & \\
\hline
\end{tabular}

Table 1.depict show the public e-procurement technology performance can help to reduce corruption in forty e-procurements. Ministry of Finance, Jogyakarta City, Tangerang City and Surabaya City are four interesting examples to increase transparencyandaccountability in public procurement. The city of Surabaya, the first city to implement e-procurement, awarded the recognition from the Anti Corruption Agency (KPK) of the succeeded city in preventing acts of corruption through the procurement of goods and services. The best model of Government e-Procurement Service could be implemented in central and regional government agencies. The e-procurement service obtained the ISO 9001: 2000 Quality Management System ISO 27001: 2005 and Information Security Management System. The impacts of the e-proc implementation in Surabaya are as follows: a) the reduced budget corruption opportunities; b)increased employment opportunities to young entrepreneurs; c). increased budget efficiency; and) increasing public trust on public procurement.

However, most of e-procurements that had been studied were to achieve efficiency and faster and easier processes of procurement rather than transparency and accountability. This is supported by Independent Monitoring Commission (LPI) in Makassar commissioner's findings were able to detect "sophisticated" practices implying collusion, such as subprojects with different types of work and locations bundled into a single package (seemingly to limit competition), bids with simple mistakes in their cost proposals (so the company would knowingly be disqualified, and the perception of more bidders would be inflated), and proposals that added items beyond the scope of work (and hid these unneeded additions by lack of detail in quantities and costs) (E. Rahman, 2012). Commissioners also found two 
bidders for a contract that had the same owner.Through its field network, LPI was also able to identify problems in contracting, such as road segments not built to specifications, volumes of supplemental food not delivered, substandard school furniture, and contractors receiving their final payments before completing work. The mayor responded to these reports by calling together department directors and pressing them to follow up on the findings. Encouragingly, the Department of Public Works heeded the call and negotiated with contractors to finish faulty infrastructure projects.

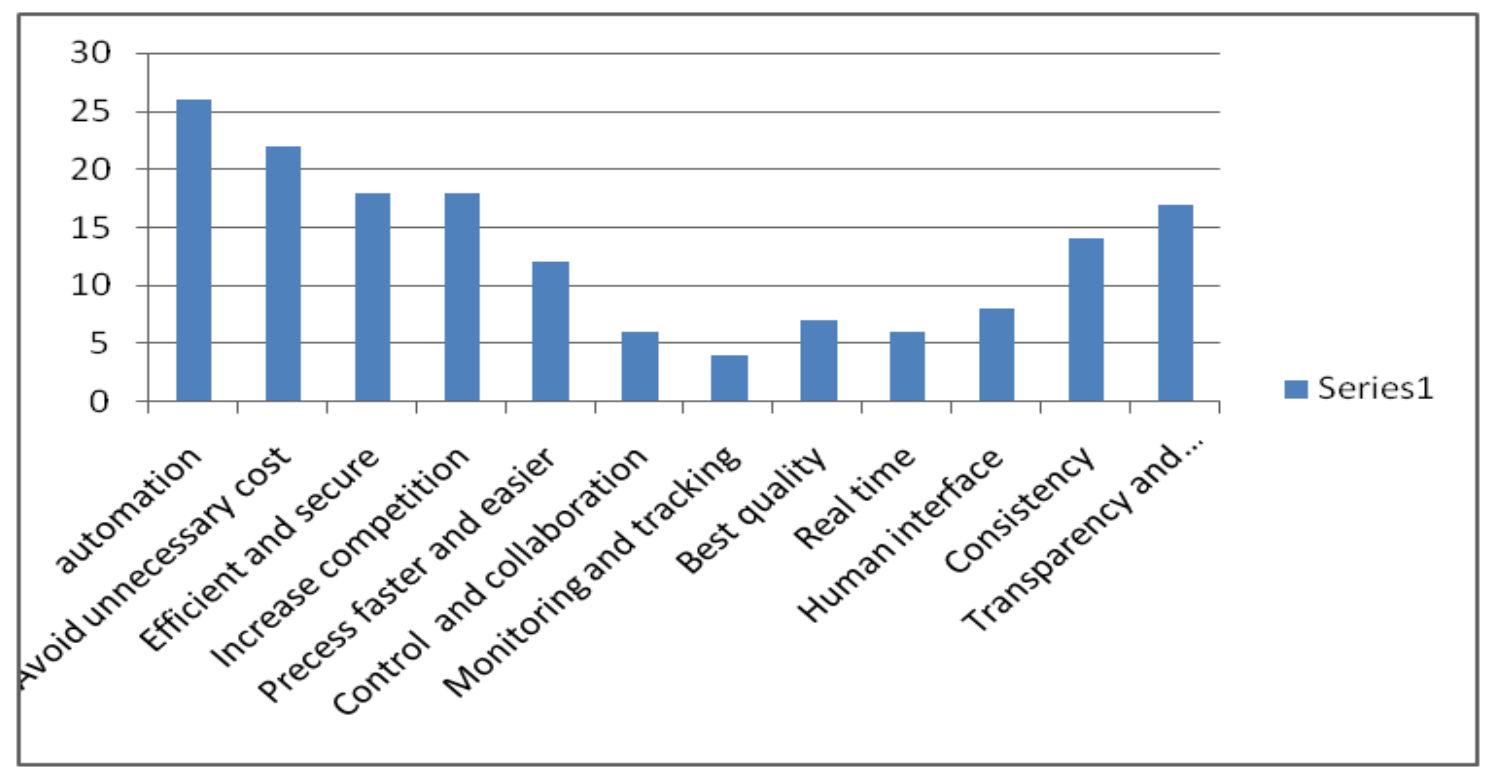

Fig.1. Anti Corruption Factors of E-Procurement

There have been 40 studies done on e-procurement conducted in forty different government organizations. Those researchers revealed that the automation (in terms of procurement process automation) has been the greatest result achieved, followed by a decrease in unnecessary costs associated with paper, and increased competition because all parties from outside the region can compete in becoming a supplier. Kusuma (2012) and Pujiati (2010) studies found that e-procurement system applications in private/government firms has a positive effect on time efficiency. 76.7\% government/private firms are categorized in the fast category in access to e-procurement sites. The ease in access to e-procurement sites is a primary advantage of conducting goods/services transactions online. E-procurement systemsmanaged by government/state firms give goods and services supplies processes good security for related relations.

As mentioned by Bawono in his research that the procurement committee agreed that eprocurementof goods/serviceswas more efficient than before:committee said that 85\% (pre tenders), 83,75 (tenders), $\%$ and $86,56 \%$ (post tender) and providers stated that e-proc making to be more efficient of $74,86 \%$ (pre tenders), 66,73\% (tenders) and 73,68\% (post tender) (Bawono, 2011).Another investigation showed that e-proc can accelerate the auction process. The number of auctions completed less than 45 days was about $50 \%$ of the whole package which was announced via the E-Procurement System. The percentage of total auctions completed between $45-60$ days is $26 \%$ while beyond day 60the percentage was $23 \%$ (Sumadilaga and Pujiono, 2011). E-procurement also increases competition, asdemonstrated by Mulyono's study in Pontianak. Construction project bidding done by Public Work Agency in Pontianak City can easily be followed by all construction companies in the city of Pontianak by utilizing the e-procurement services (Mulyono, et. al, 2011).This study analyzes the implementation of e-procurement policy in PLN for realizing efficiency and transparency, as 
well as the problems which are encountered in the implementation of e-procurement (Rahayu, et. al, 2011).

\section{Procurement Officer Perception on Corruption in Procurement}

In this section, we tested the relationship between procurement information, completeness of information, information on evaluation, contract mechanism, and opportunistic behavior on eprocurement implementation. The Pearson correlation coefficient is around 0.324 to 0.636. This mean $\mathrm{H}_{\mathrm{s}}$ is accepted that all independent variables are positively related to dependent variable. Information on procurement, information on procurement plans, information on evaluation, contract mechanisms, and opportunistic behavior all have relationships with eprocurement implementation.

Table. 2. Perception on Political Behavior on Procurement Process

\begin{tabular}{|c|c|c|c|c|c|c|c|}
\hline & & $\begin{array}{l}\text { E_Proc } \\
\text { Imp }\end{array}$ & $\begin{array}{c}\text { Informati } \\
\text { on on } \\
\text { Proc }\end{array}$ & $\begin{array}{c}\text { Informatio } \\
n\end{array}$ & $\begin{array}{c}\text { Evaluation } \\
\text { Informatio } \\
n\end{array}$ & $\begin{array}{c}\text { Contract } \\
\text { mechanis } \\
\text { m }\end{array}$ & $\begin{array}{c}\text { Opportunis } \\
\text { tic } \\
\text { behavior }\end{array}$ \\
\hline \multirow[t]{3}{*}{ E_Proc Imp } & $\begin{array}{l}\text { Pearson } \\
\text { Correlation }\end{array}$ & 1 & $.501^{* *}$ & $.385^{*}$ & .324 & .346 & $.636^{* *}$ \\
\hline & $\begin{array}{l}\text { Sig. (2- } \\
\text { tailed) }\end{array}$ & & .007 & .043 & .093 & .071 & .000 \\
\hline & $\mathrm{N}$ & 120 & 120 & 120 & 120 & 120 & 120 \\
\hline \multirow[t]{3}{*}{ Information on Proc } & $\begin{array}{l}\text { Pearson } \\
\text { Correlation }\end{array}$ & & 1 & $.748^{* *}$ & .374 & $.496^{* *}$ & $.608^{* *}$ \\
\hline & $\begin{array}{l}\text { Sig. (2- } \\
\text { tailed) }\end{array}$ & & & .000 & .050 & .007 & .001 \\
\hline & $\mathrm{N}$ & & 120 & 120 & 120 & 120 & 120 \\
\hline \multirow[t]{3}{*}{ Information } & $\begin{array}{l}\text { Pearson } \\
\text { Correlation }\end{array}$ & & & 1 & $.491^{* *}$ & $.723^{* *}$ & $.627^{* *}$ \\
\hline & $\begin{array}{l}\text { Sig. (2- } \\
\text { tailed) }\end{array}$ & & & & .008 & .000 & .000 \\
\hline & $\mathrm{N}$ & & & 120 & 120 & 120 & 120 \\
\hline \multirow[t]{3}{*}{$\begin{array}{l}\text { Evaluation } \\
\text { Information }\end{array}$} & $\begin{array}{l}\text { Pearson } \\
\text { Correlation }\end{array}$ & & & & 1 & $.803^{* *}$ & $.488^{* *}$ \\
\hline & $\begin{array}{l}\text { Sig. (2- } \\
\text { tailed) }\end{array}$ & & & & & .000 & .008 \\
\hline & $\mathrm{N}$ & & & & 120 & 120 & 120 \\
\hline \multirow[t]{3}{*}{ Contract mechanism } & $\begin{array}{l}\text { Pearson } \\
\text { Correlation }\end{array}$ & & & & & 1 & $.559^{* *}$ \\
\hline & $\begin{array}{l}\text { Sig. (2- } \\
\text { tailed) }\end{array}$ & & & & & & .002 \\
\hline & $\mathrm{N}$ & & & & & 120 & 120 \\
\hline \multirow[t]{3}{*}{$\begin{array}{l}\text { Opportunistic } \\
\text { behavior }\end{array}$} & $\begin{array}{l}\text { Pearson } \\
\text { Correlation }\end{array}$ & & & & & & 1 \\
\hline & $\begin{array}{l}\text { Sig. (2- } \\
\text { tailed) }\end{array}$ & & & & & & \\
\hline & $\mathrm{N}$ & & & & & & 120 \\
\hline
\end{tabular}

**. Correlation is significant at the 0.01 level (2-tailed).

*. Correlation is significant at the 0.05 level (2-tailed). 
The following step is to test the degree of those relationships with a regression test. The regression test showed that information on e-procurement and opportunistic behavior has a strong influence on e-procurement implementation.

Table 2. Regression Test

\begin{tabular}{|c|l|c|}
\hline No & \multicolumn{1}{|c|}{ Variable } & Significant test \\
\hline 1 & Variable 1 & 0,888 \\
\hline 2 & Variable 2 & 0,297 \\
\hline 3 & Variable 3 & 0,600 \\
\hline 4 & Variable 4 & 0,732 \\
\hline 5 & Variable5 & 0,900 \\
\hline
\end{tabular}

\section{Elite Capture and Collection Action in Procurement}

Interestingly, the procuring game was redefined after e-procurement implementation in Yogyakarta city and Tangerang city. Information asymmetry was reduced by information technology. Interest groups, associations of companies and media now had access to procurement process and could use this information from website to push for a more transparent process. The Head of the Planning Agency inTangerang City said that:

"After implementing e-procurement, we (budget-owned agency) could not control whowon the bidding. Because, the procurement agency is a very independent unit that we could be not interfere with. And also the all bidders could look at the procurement process from the e-procurement website. Before implementing eprocurement, the budget-owner agency had the bidding winner, therefore procurement processes were the only justification for it."

The head of the Procurement unit in Tangerang city stated that:

Through the e-procurement mechanism, it is difficult to intervene in procurement decision making processes due to all steps being recorded. It is too risky to change the decision because NPA systems are always connected with Tangerang's eprocurement site. In the early implementation, local politicians tried to intervene in the procurement process, but they could not do it. In the end, they supported the eprocurement process.

These statements of Tangerang city officials confirmed that there are some external environmental factors importantly affecting the "local politician behavior regarding the procurement process". Those factors are local politics in Tangerangand Yogyakarta. The following interview was done with local politician of Yogyakarta council below:

"We, as a local council institution, only had political control on procurement process. Legally local council members were not permitted involving in goods and services purchasing.In Yogyakarta, local councils could not intervene withprocurement process due to intense public watch dogs"

The political positions of NGOs may be strong in Yogyakarta Special Province and can face head-to-head to local parliament. The strong institutions of society are also indicated by the survey results from Partnership Indonesia in 2012. The interaction of the arena is already well underway. It can be concluded from the communication between the arenathat the process is going well and the availability of forums that bring together representatives has the functions of each arena. The forum is between the local council and the bureaucracy, the government and the community, the government andthe economic community. The forums were convened on a regular basis in an effort to absorb the public aspirations for policy makers. Even though there 
was high public participation in the forums, it was unfortunately considered an ineffective method. The forums were attended by under-represented groups(IGI, 2013).

The principle of transparency in the province of DIY is better than any national average for all arenas. The bureaucratic arena has the highest index value, i.e. 9.09 (very good), which is higher than the national average of 5.05 (enough). The government area followed with a 7.97 value (good), which is better than the national average on 4.58 (tend to be bad). As for the arena of civil society and economic community, both have the same index value i.e. 6.40 (tend to be good), both higher than the national average at 6.28 (likely both) in civil society arena and 5.80 (enough) in the economic community arena. Meanwhile, according to Mohammad Faried Cahyono-DIY IGI Investigators said that DIY gained value at 6.80 and was above the national average: 5.67.This means that the good performance in principles of transparency, accountability, participation, fairness, effectiveness and efficiency in the arena of government, bureaucracy, civil society, and the economic community. One of bureaucratic transparency achieved a value of 10 . Another factor assessment is the ease in accessing public documents through the official government website.

The case of public procurement exercising control over agents is much more complicated. Firstly, there is no homogenous group of principals to monitor the actions taken by the agent. Instead there is a diverse collection of principals, composed of interests represented by pressure groups influencing politicians and the general public. The first consists of ex ante measures, which will often take the form of administrative procedures integrated into the domestic public procurement regulation. The second takes the form of ex post oversight, which will be mostly external to the procurement regulation and consist of ministerial control, the existence of superior authorities or commissioners and judicial review (Sourdy, 2007). In Yogyakarta Special Province, Local Ombudsman Institute acts an oversight control institution to control the procurement process through information technology.

\section{SMS GATEWAY (08112741000)}

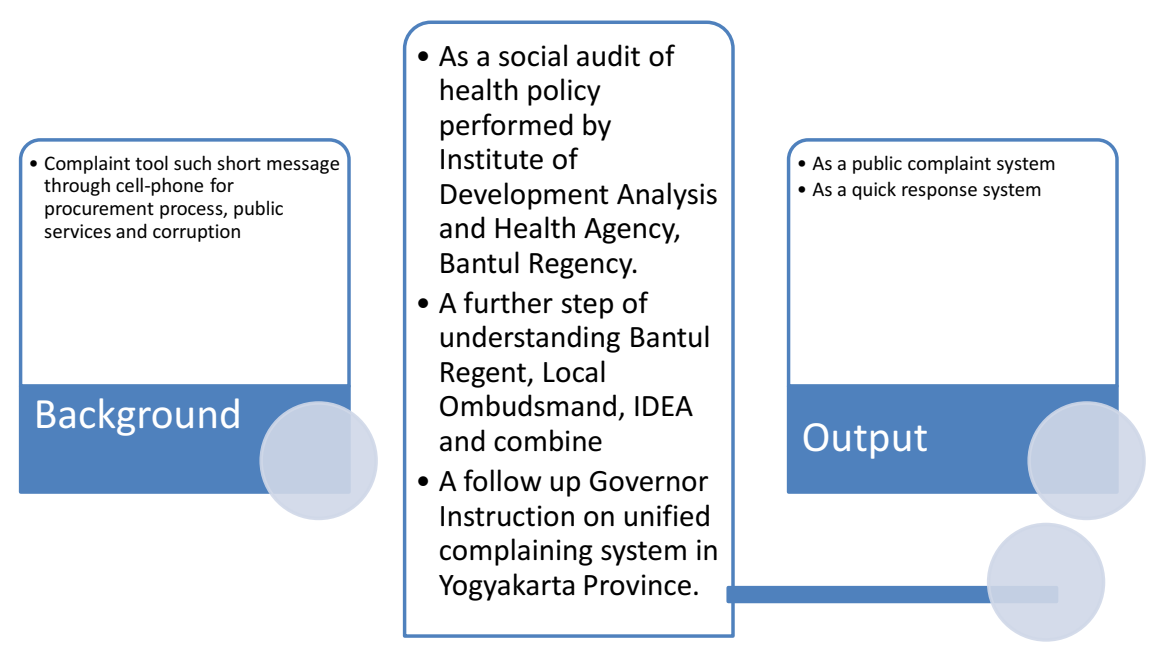

Fig. 2 Oversight Control on Public Procurement in Yogyakarta Province

However, political commitment to health and education budgets was the lowest compare with other provinces. Those showed the ratio of girls to boys, and it shows that in the special region of Yogyakarta (DIY) girls receive only 8.6 years, whereas the minimum requirement for 
compulsory education is nine years and the health budget allocations per year are only IDR 5.807 per resident. This fact is contrary to the magnitude of the operational costs of the bureaucracy, i.e. overhead at DIY is about $96 \%$ of the cost of the total program. As a consequence, the principles of fairness and efficiency in the arena of government get the lowest value when weighed against other principles.

Another analysis on Yogyakarta and Tangerang local politics concerns whether the competition amongst political parties in local councils is high or low. The most important indicator to measure the degree of competitiveness is the holder of the executive wing and the legislative wing. There are two types of local government in the current local government in Indonesia, namely the divided local government system and the unified government system. In the divided government system, the mayor/regent/governor is from one party, but the majority of local parliament is dominated by another party. In the unified local government system, the mayor/regent/governor is from the majority party holding the local parliament. We assume that competition amongstpoliticians in thedivided local government systemis stronger than in the unified one. What is the effect of political competition on procurement process? If competition between political parties and between councils is effective,then local service producers may already be highly efficient (Boyne, 1998).

In Yogyakarta city, Haryadi Suyuti - Imam Priyono (mayor and vice mayor) nominated by Indonesia Struggle Democratic Party (PDIP) and Golkar Party won the popular vote at 48, 34 percent ( $42.5 \%$ in city parliament) defeated Hanafi Rais - Tri Harjun Ismaji (Fitri), mayor candidate of National Mandatory Party (PAN), Democratic Party (PD), United Development Party (PPP), Gerindra Party Hanafi Rais - Tri Harjun Ismaji (Fitri). Meantime, in Tangerang city, mayor candidate Wahidin Halim and Arief Wismansyah supported by twelve political parties: Partai Golkar, PDI Perjuangan, PPP, PAN, PKPB, Partai Demokrat, PDS, Partai Bulan Bintang, and PKNU won popular vote at $72.73 \%$. In fact, the thesis of political competition is not valid in two city cases because Yogyakarta and Tangerang city classified as an unified government system.

\section{Elite Capture Riau Island Province Procurement}

The Riau Island Province, with Tanjungpinang as the capital, is the newest province of Riau Province. Its territory includes 2 cities and 5 regencies. Tanjungpinang City,Batam city, Karimun Regency,Lingga Regency, Natuna Islands regency, and Anambas Islands Regency. Administratively, Riau Province has 59 districts and 351 sub-districts. Its areaof251,810.71km squared is dominated by sea, which consists of $241,215.30 \mathrm{~km}(95,79 \%)$. The remaining,4,110,595 miles (4.21\%) is land that is spread out among the 366 large and small islands, of which $40 \%$ have not yet been named and populated. Among the thousands of islands, 19 of the outermost islandsare directly adjacent to the another country(Malaysia or Singapore) that is prone to security issues, social welfare issues, and environmental sustainability issues.

From all over the arena or governance aspect of Riau Island Province, the application of the principle of transparency of the Bureaucratic Arena only amounted to 2.34 (bad). While the highest index was obtained by the Government Arena in applying the principles of efficiency getting score on 8,19 (good). The research showed the index governance of Riau Island Province value to be 5.60 (enough), 0.10 lower than the national average index whose value is 5.70. Riau Island province's index value placed it at the 24 th position out of the 32 provinces. The bureaucratic Arena'slowest index was of 2.34 (bad), which is earned in the transparency category. This index is big gap from the national average of 5.04 (enough). The highest index was obtained by the Economic Community Arena, at 5.50 (enough). If compared to the national average, all arenas in the province hada lower index of the principle of transparency(IGI, 2013). 
It is interesting to look at the configuration of the local politics in term of political parties winningthe general elections in 2009. Of the 45 seats in the local parliament, the Democrat Party and Golkar Party each gained control of $15.56 \%$ (7 seats), the PDI-P and the PKS have each $13,33 \%$ (6 seats) and $11.11 \%$ (5 seats), the PPP has 4 seats $(8,89 \%)$, Partai Indonesia Baru has 3 seats $(6,67 \%)$, and the Hanura get two seats or $4.44 \%)$, and the other five parties have 1 seat each. In other words, province of Riau Islands controlled politically by the PartaiDemokrat, the Golkar party, PDI-P and PKS. Meanwhile in the executive wing, the Governor and Deputy Governor, Mohammad Respationo and Sani Soerya, candidacy of the PDIP won local election vote after getting $23.2 \%$ of the vote from 621,847 votes in the 2010 's election.

By using the Ostrom's model, it may assume that the local politicians, bureaucrats, and private companies in Riau Provinces organizes and govern themselves to obtain benefit from "eprocurement" regulation. They did preparation from the budget planning until project procurement announcement in site.

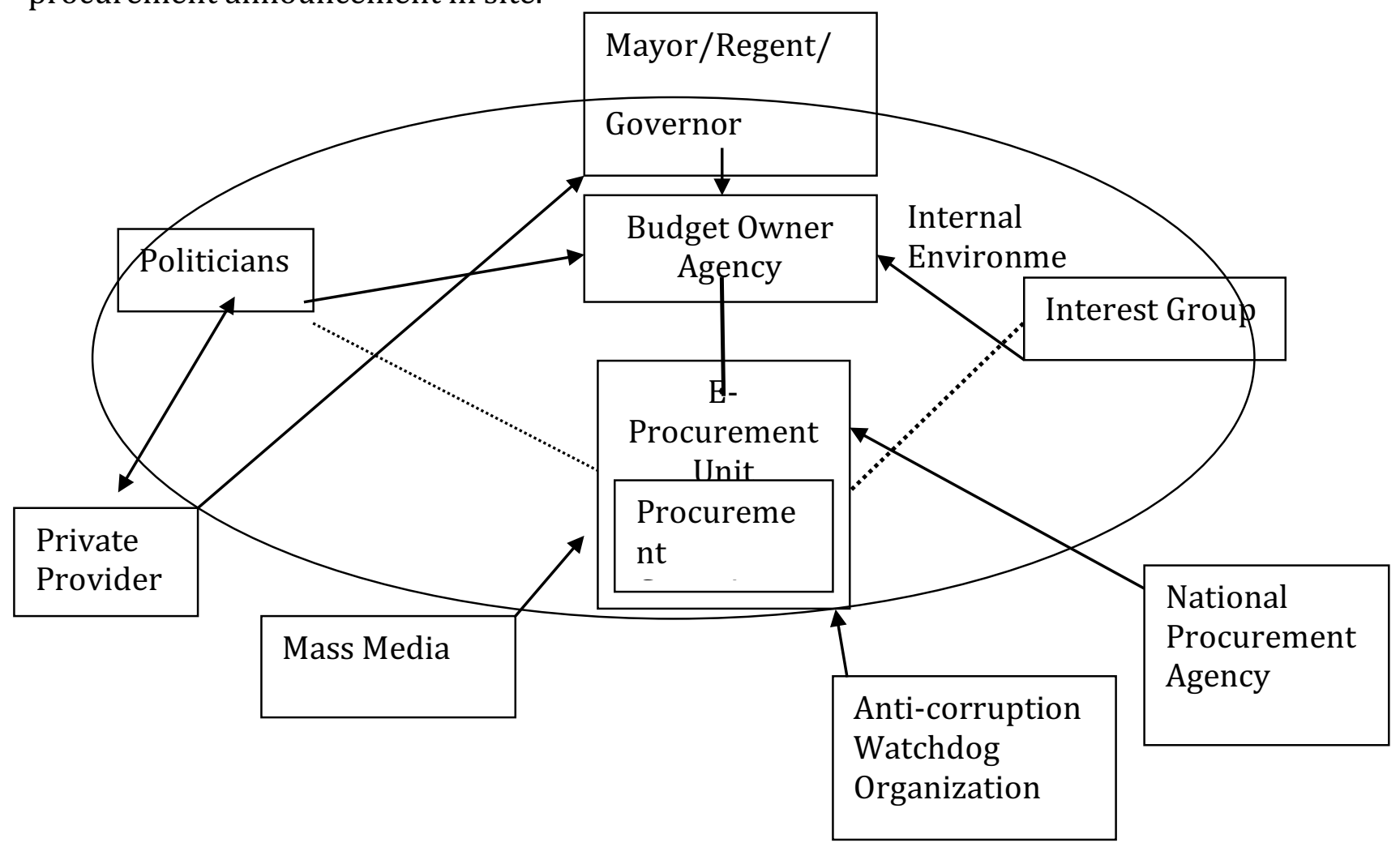

Fig.3. Political Configuration in Local Procurement

In Fig 3 above, there are some actors who have an interest in local procurement. Mayor/regent/governor is the key person who has authority to use the local budget. Under his/her leadership, she/he proposes a budget draft to the local council in order to get the council's approval. The budget debate in the local parliament normally occurs from August to November every year. In the discussion of the budget in the local parliament occur politician budget proposed by members of parliament to executive partners. If it is not approved by the executive, the parliament will not approve the proposed budget plan. The process of corruption at the budget planning level is publicly known in the Riau Islands province. TheGetuk, a corruption watchdog organization in Tanjungpinang, found the seminal case as follows:

There were two local parliament members, Rizky Faisal of Golkar Party and Iskandarsyah of PKS party, who were alleged to be middlemen in the Education 
Agency and the Health Agency, Riau Island Province. Therefore, the e-procurement mechanism was only a justification to meet the procurement rule. YusriSabri, aanti corruption activist saidthat he had strong evidence to prove his allegation. He added moreover that those agencies, private company providers, and local parliament members collaborated to arrange a billion rupiah project. Even YusriSabri said that a private company had provided Rp. 600 million for success fee of Rp. 13 billion's project (Batamcom, 2013/October 16).

Another investigation done by Suparman, the Head of Local Transparency Organization, Batam City, promulgates the other case. This case shows how the e-procurement process is designed to guarantee a winning candidate through violation of procurement procedure.

A maintenance road project in Batamwas announced through e-procurement site. But, the bidding document on October 132012 had never been done by the procurement committee. Bidding evaluation occurred on 30 October 2012, the same day thebidding document was opened. The bidding document could not be downloaded or uploaded through the e-procurement site. And the objection period from 2 November to 7 November 2013 was unavailable. Suparman alleged that PT. Paten Agriutama as a project winner being get early agreement with procurement committee to win the project. In the project implementation, the road cement did meet the required specification of cement quality.(2013/February 2, Bakin News).

Those cases revealed that e-procurement in remote areas and the far-reaching control of NPA is facing transparency problem. Through public goods and services purchases via eprocurement, all actors organize themselves in order to obtain their interests. This will, however, also imply a simplification of the opportunities for corruption (Soreide, 2002). Again, confidential information is an attractive commodity, inmany cases worth a significant bribe (Soreide, 2002).Pearsson, et al (2010) also found in Kenya and Uganda that the collective action problem of corruption is not as one sided as it may look. Even actors higher up in the hierarchy - such as low-level public officials andpolitical elites - seem to feel a pressure to passively support the corrupt game rather than activelytaking part in it for their own private, absolute gain.

Business deals in e-procurement may be happened in which a private company tries to lobby budget officials and procurement officials and get political support from politicians in local parliament. In turn, they lobby procurement committees in order to win the bidding.(Interviewer P.3. Nov/2013/14)

The absence of standardized monitoring also occurs at auctions in the case ofBatamAgency in Riau Islands. In the case of auctions that occur, the decisions of the committee are not obeyed by the owner's budget official, so the auction was won by one of the companies which was not running. There are indications that the desired second-order functions fromofficial commitments. Corporate winners then asksthe claim to owner official but is not addressed properly. In this process it can be said that there is no system of control and monitoring from the NPA, so there are many cases of irregularities in the procurement of goods and services via e-procurement which are not resolved.

However, the survey of the Anti-Corruption Agency(KPK) on corruption prevention revealed that the role of the community in the prevention of corruption is quite low. Certainly, every government unit generally delivers the media and complaint mechanismsin optimizing customer satisfaction. Of 1125 respondents, only 45.8 percent of service users know there is a media complaint, while $10.2 \%$ of the service users had complained (KPK, 2012). Moreover, the 
respondents were asked about their actions on corruption, which revealed that there is variation in answers as follows:
a. Not doing anything without any reasons.
b. They felt that they did not have authority to do and they felt useless.
c. Not doing anything and just to pray.
d. They did not do anything, because they did not care. They said there was some institutions that dealing with.
e. They did not do anything, because there were too few of them.
f. They did know what to do and to whom to report.

\section{DISCUSSION}

The fact above shows that some anti-corruption policies under the principal-agency theory is a failure of reforms or are also not so much the result of a lack of resources as of the absence of stakeholders -including government, civil society, non-governmental organizations, and ordinary citizens - willing to act as "principals" and, as such, enforce existing laws and policies (Pearsson, 2010; Riley 1998; Robinson 1998;Kpundeh 1998, 2004; Johnston 2005; Amundsen 2006; World Bank 1994). In decentralized procurement of Indonesia, public participation is very important to prevent the misuse of local budgets. Decentralization may be particularly successful where there is local capacity and high levels of participation (Hanna, 2011). Decentralization can reduce corruption by bringing the accountability for program implementation to the effectiveness of anti-corruption policy.

Lack of public knowledge on the procurement of goods and services is likely a common fact and even some of those who are still considered the winners of an unworthy company arecommonly accepted. A survey conducted by the Anti-Corruption Agency on public perception of corruption found interesting findings especially with regard to goods and services procurement. Responding to the whether the act of public officials as procurement committee inwinning the their closed-family company despite the offer not the best, 20.9\% (in a 2010 survey ) and decrease to $16.7 \%$ (in a 2014 survey) of respondents said this was not corruption and $6.58 \%$ (in a 2010 survey) and increased to $11.2 \%$ (in a 2014 survey) of them did not know (KPK, 2014). Similarly another finding on gratification in the procurement process shows the degree of public awareness on corruption. In both the 2010 and the 2011 survey there were $52.5 \%$ and $52.7 \%$ of respondents which said the gratification in procurement process was not corruption. $32.2 \%$ of respondent said they did know of any corruption or conflict ofinterest in procurement process (KPK, 2014).

\section{CONCLUSION}

Having more information on different perspectives on public awareness on potential corruption in procurement process, we can summarize a different story, in either a success story or a failure story of e-procurement to prevent corruption. Certainly, Riau Island Province, the newest local government, the public participation and public capability in public policy is still developing and immature. This province needs time to build its community capacity. In Yogyakarta and Tangerang---with more governane capability--- procurement initiative could improve not only efficiency but also transparancy and accountability. This means the more civil organization participation the more qualified procurement process.

\section{References}

Ancarani A. (2009) Supplier evaluation in local public services: Application of a model of value for customer. Journal of Purchasing and Supply Management 15: 33-42.

Barahona JC and Elizondo AM. (2012) The Disruptive Innovation Theory Applied to National Implementations of E-procurement. Electronic Journal of e-Government 10. 
Chiang L and Hsieh T-C. (2007) Information integration to create an infrastructure: facilitating public service provisioning in Taiwan. Electronic Journal of e-Government 5: 29-42.

Coggburn JD. (2003) Exploring differences in the American states' procurement practices. Journal of Public Procurement 3: 3-28.

Coulthard D and Castleman T. (2001) Electronic procurement in government: More complicated than just good business. ECIS 2001 Proceedings: 34.

Croom SR and Brandon-Jones A. (2005) Key issues in e-procurement: procurement implementation and operation in the public sector. Journal of Public Procurement 5: 367.

ECOM Group. (2002) e-Procurement in the UK Public Sector: A Guide to Developments and Best Practices. A CIPFA e-Government Forum Report). London, UK.

Engstrom A, Wallstrom A and Salehi-Sangari E. (2009) Implementation of public e-procurement in Swedish government entities. Computer Science and Information Technology, 2009. IMCSIT'09. International Multiconference on. IEEE, 315-319.

Furuholt B and Wahid F. (2008) E-government Challenges and the Role of Political Leadership in Indonesia: the Case of Sragen. Hawaii International Conference on System Sciences, Proceedings of the 41st Annual. IEEE, 411-411.

Ha H and Coghill K. (2006) E-Government in Singapore-A Swot and Pest Analysis. Asia-Pacific Social Science Review 6: 103-130.

Henriksen HZ, Mahnke V and Hansen JM. (2004) Public e-procurement adoption: economic and political rationality. System Sciences, 2004. Proceedings of the 37th Annual Hawaii International Conference on. 9 pp.

Huntgeburth JC, Steininger DM, Parasie NP. (2012) Increasing the Adoption of E-Procurement Services at the Municipal Level. e-Service Journal 8: 3-23.

Khan S. (2013) Unwritten ground rules (UGRs) in public procurement in developing countries. Journal of Public Procurement 13: 176.

Lim JH. (2010) Digital Divides in Urban E-Government in South Korea: Exploring Differences in Municipalities' Use of the Internet for Environmental Governance. Policy \& Internet 2: 31-68.

MacManus SA. (2002) Understanding the incremental nature of e-procurement implementation at the state and local levels. Journal of Public Procurement 2: 5-28.

Moon MJ. (2005) E-procurement management in state governments: diffusion of e-procurement practices and its determinants. Journal of Public Procurement 5: 54-72.

Murray JG. (2009) Improving the validity of public procurement research. International Journal of Public Sector Management 22: 91-103.

Nightisabha IA, Suhardjanto D and Cahya BT. (2009) Persepsi pengguna layanan pengadaan barang dan jasa pada pemerintah kota Yogyakarta terhadap implementasi sistem e-procurement. Jurnal Siasat Bisnis 13: 129-150.

Nurmandi, A., \& Kim, S. (2015). Making e-procurement work in a decentralized procurement system: A comparison of three Indonesian cities. International Journal of Public Sector Management, 28(3), 198-220.

Office of Government Commerce(OGC). (2002) A guide to e-Procurement for the public sector, Office of Government Commerce. London.

Panda P, Sahu G and Gupta P. (2010) Promoting transparency and efficiency in Public Procurements: eProcurement Initiatives by Government of India. 7th International Conference on E-Government.

Purchase S, Goh T and Dooley K. (2009) Supplier perceived value: differences between business-to-business and business-to-government relationships. Journal of Purchasing and Supply Management 15: 3-11.

Rudianto Y. (2012) GOOD GOVERNANCE, NASIONALISME, DAN PENGADAAN BARANG/JASA PEMERINTAH. Jurnal FISIP: MADANI 13.

Soekiman A and Saputra F. (2010) STUDY OF E-PROCUREMENT IMPLEMENTATION IN GOVERNMENT'S GOODS/SERVICES IN INDONESIA. International Journal of Engineering 8.

Stenning\&AssociatesPtyLtd.(S\&A). (2003) Final Report: Evaluation and Review of the e-Procurement Pilot Project Version 1. 2. Hobart, Australia.

Transparency International-USA and Enterprise C. (2011) APEC Procurement Transparency in Indonesia. In: (TIUSA) LBS and (CIPE) AN (eds). Jakarta. 
UN ESCAP. (2006) E-Procurement. Thailand: United Nation Publication.

Utama AS and Djunaedi IA. (2011) Pengalaman Penerapan E-Procurement Di Pemerintah Daerah (Studi Kasus: EProcurement Pemerintah Kota Yogyakarta. Universitas Gadjah Mada.

Vaidya K, Sajeev A and Callender G. (2006) Critical factors that influence e-procurement implementation success in the public sector. Journal of Public Procurement 6: 70.

Wahid F. (2012) Institutionalization of public systems in developing countries: a case study of eProcurement in Indonesian local government. Proceedings of the Transforming Government Workshop. Brunel University.

World Bank. (2003) Electronic Government Procurement(e-GP): World Bank Draft Strategy. Washington, D.C.: World Bank. 